\title{
UNIVERSAL CHILD ALLOWANCE AND SCHOOL DELAY OF CHILDREN IN ARGENTINA*
}

\section{LA ASIGNACION UNIVERSAL POR HIJO Y EL RETRASO ESCOLAR DE LOS NIÑOS EN ARGENTINA}

\section{VANESA VALERIA D’ELIA**}

Universidad del CEMA and ANSES

\section{ANA INES NAVARRO***}

Universidad Austral

\begin{abstract}
This paper empirically explores the effect of the Universal Child Allowance - a conditional Cash Transfer Program recently launched in Argentina- on backwardness in school. Specifically, we evaluate whether children enrolled in the program closed their education gap, differentiating between children and adolescents.

Using propensity score as a prelude to the estimation of regression, we found preliminary evidence that the government subsidy affects primary and secondary students differently. The results are robust to different uses of the different samples and comparison samples observation.
\end{abstract}

Keywords: Universal Child Allowance, poverty-alleviation program, schooling gap, Argentina.

JEL Classification: I24, I38, C21.

* The authors thank the helpful suggestions of Leonardo Gasparini. The paper also benefited from the comments of the attendants to the XLVI Reunión Anual de la Asociación Argentina de Economía Politica and to the 12th annual University of North Florida - University of Warsaw International Business conference on Research, Teaching and Practice.

** Avenida Córdoba 720, C1054AAT, Buenos Aires, Argentina. Tel.: 5411 40159215. E-mail: vanesadelia@ anses.gov.ar

*** Paraguay 1950, 2000 Rosario, Argentina. Tel.: 54341522 3000. E-mail: anavarro@austral.edu.ar. Corresponding Author. 


\title{
Resumen
}

\begin{abstract}
Este trabajo explora empíricamente el efecto de la Asignación Universal por Hijo -un programa de transferencias condicionadas de ingresos recientemente implementado en la Argentina- en el atraso escolar de los niños beneficiarios. Específicamente, evaluamos si los niños inscriptos en el programa mejoraron su brecha educativa, diferenciando entre niños y adolescentes.

Utilizando propensity score previo a la estimación de las regresiones, encontramos evidencia preliminar de que el subsidio afecta de manera diferente a los estudiantes de primaria y de secundaria. Los resultados son robustos a diferentes definiciones de la muestra estudiada y de las muestras de comparación.
\end{abstract}

Palabras clave: Asignación Universal por Hijo, programa de alivio de la pobreza, retraso escolar, Argentina.

Clasificación JEL: I24, I38, C21.

\section{INTRODUCTION}

Despite the economic recovery that followed the monumental crisis suffered by Argentina in 2001-2002, a significant percentage of the population still lived in poverty seven years later. Worst of all, the group most affected by poverty were children and youth, who can do little to better their state with the consequence that this will have a lasting impact on their lives (Gasparini and Cruces, 2010). At the end of 2009, aware of the seriousness of the problem and strongly pressed by the opposition, the government decided to implement, by means of an Executive Order, a conditional Cash Transfer Program (henceforth CCT) for unemployed and informal workers with children under eighteen years of age called "Universal Child Allowance" (henceforth UCA). There is some preliminary evidence that the UCA has been favorable in terms of reducing poverty. According to Gasparini and Cruces (2010), Gonzalez Rozada (2010) and D'Elia et al. (2010) poverty rates and, specially, child poverty rates, have fallen down since the implementation of UCA. Similar to other existing plans implemented in several Latin American countries, the subsidy was also designed to increase the human capital of children requiring parents to meet the schedule of vaccines for their children and school attendance. The Ministry of Education of Argentina says there is a favorable incidence of the subsidy on children's school attendance and, a recent study conducted by the Centro de Estudios en Políticas Públicas (CEPP) 2011, and the Universidad de Buenos Aires (UBA) shows that, according to the principals of the schools surveyed, the reinsertion rate into secondary school is larger than into primary.

A number of empirical studies indicate that CCT programs are able to induce poor households to invest in the human capital of their children who benefit from 
increased use of the health services and school attendance (Skoufias and McClafferty, 2001; Glewwe and Olinto, 2004; Attanasio, Fitzsimons and Gomez, 2005; Maluccio and Flores, 2005; Galasso, 2006; Schady and Araujo, 2008; Bobonis and Finan, 2009; Soares, Perez and Guerreiro, 2010; IEG, 2011; Glewwe and Kassouf, 2012) as well as some others indicate otherwise (Perova and Vakis, 2009). There is much less evidence about the success of CCTs in terms of educational attainment or academic performance of the children; furthermore, these studies show mixed results. Fiszbein and Schady (2009) study the effect of CCTs in several low and middle income countries of Latin America and the Caribbean, Asia and Africa and conclude that CCTs appear to have had a modest impact on years of schooling completed by adults and although they resulted in a modest improvement in cognitive development among the very young children, the CCTs had no discernible effect on learning outcomes for the benefited children while they were of school age. Baez and Camacho (2011) show that the transfer recipients in Colombia who graduate from high school seem to perform at the same level as equally poor non-recipients graduates and; Ponce and Bedi (2010) also find no positive impact on test scores in Honduras.

The main theme of this work is the impact of a program of poverty alleviation in the stock of human capital of poor children in Argentina. The aim of this study is to investigate the early effects of the UCA on the school delay of the benefiting children. The scope of the study is limited for three main topics. The first is that the UCA has been recently implemented and knowing the long term effects will require waiting several years. The second concerns the fact that the surveys database we employed is published with some delay so we did not have data for 2011 when doing our estimations. Finally, and far more important is that the implementation of the program was not accompanied by a mechanism to assess its impact on the generation of human capital of children benefited. This is one of the main reasons so few long-term studies in Latin America focus primarily in Mexico (Behrman, Parker and Todd, 2005; Behrman and Parker, 2008) or more recently in Colombia (Báez and Camacho, 2011) where execution of CCT was accompanied with a mechanism to evaluate the results.

This is the first study that analyzes the UCA effect on the children's backwardness in school. Based on a standard methodology (Behrman, Birdsall and Székely, 1998; Andersen, 2001; Dahan and Gaviria, 2001) for estimating intergenerational educational mobility, and following the approach proposed by Crump et al. (2006) for pre-selecting comparable groups, at least in observable characteristics, this study measures the schooling gap effect on a child raised in a family enrolled in this social assistance program. The analysis is based on the Argentinean Permanent Household Survey (Encuesta Permanente de Hogares, EPH), carried out by the Instituto Nacional de Estadística y Censos, (National Institute of Statistics and Censuses, INDEC) and data from the Administración Nacional de la Seguridad Social (National Social Security Administration, ANSES), the government agency that funds and manages the program.

The remainder of the present paper is organized as follows. An overview of the conditional cash transfer programs in Latin American countries and the description of the Argentinean UCA subsidy are presented in the next section. Section 3 describes the data and its limitations. Section 4 presents the empirical strategy to estimate the effect of UCA on education. Section 5 summarizes the main results, and Section 6 concludes. 


\section{CONDITIONAL CASHTRANSFERS EXPERIENCES IN LATINAMERICAN COUNTRIES}

In the last decades, conditional cash transfers (CCT) have become one of the core components of public policy against poverty in several Latin American countries. The earliest experiences are those of Brazil and Mexico in the late 90's. From early 2000, other countries such as Chile, Peru, Colombia, Ecuador, Honduras and Nicaragua also implemented programs of conditional cash transfers to promote to enhance children's human capital formation.

One of the pioneering countries in implementing CCT in the region was Brazil. In the late 90's, it created the Plan Bolsa Escola which consisted in a cash transfer to promote primary education and the Programa de Erradicacao do Trabalho Infantil (PETI) with the purpose to eliminate hazardous child labour. According to Soares, Perez and Guerreiro (2010), the program shows improvements in poverty and inequality indicators and a clearly positive impact in schooling (although this is not the case for health issues). Glewwe and Kassouf (2012) estimate that the Bolsa Program increased school enrollment in grades $1-4$ by about $2.8 \%$ in the initial years and by $5.5 \%$ in the long run. They also estimate that the plan reduced the dropout rate by $0.3 \mathrm{pp}$ in the first year and by $0.55 \mathrm{pp}$ in the long run, and that increased the grade promotion rate.

Later, in 2002 Mexico implemented the Oportunidades Program based on the Progresa Program created in 1997. Concerning educational results, some studies show improvement in schooling level and enrollment in rural schools, as well as a decrease in desertion and repetition rates. It is estimated that the enrollment rate has increased between 10 and $20 \%$ and that there have been an increase of $10 \%$ in years of schooling of poor children (Skoufias and McClafferty, 2001). The program also appears to have had positive spillover effects-school enrollment increased even among children above the cut-off point of the proxy means who were ineligible for transfers. Bobonis and Finan (2009) argue that the increase was a result of peer effects-barely ineligible children in Oportunidades communities were more likely to enroll because their eligible peers were in school.

Moreover, in 2002 it was implemented the Chile Solidario Program which is focused on overcoming extreme poverty and is oriented at caring for families, people and territories in situation of vulnerability in Chile. Galasso (2006) analyzes the impact of the program on a variety of outcomes, including preschool and school enrollment. She estimates positive effects of 4 to 5 percentage points (pp) on preschool enrollment and of approximately $7 \mathrm{pp}$ on the probability that all children aged between 6 and 14 are enrolled in school.

On the contrary, the effects on education of the Peruvian Program called Juntos were not significant. This program, created in 2005 is a National Direct Support Program for the poorest, aiming at fighting chronic child malnutrition and extreme poverty, where rural areas are considered a priority. According to Perova and Vakis (2009), the impact on school enrollment is not relevant (an increase of $4 \mathrm{pp}$ ) and there is not any effect on total attendance. However, there is a positive impact in both indicators in the "transition" ages (i.e. in children 7 and 13 years old who move to the primary level and from primary to secondary school). 
In Honduras, at early nineties, the Programa de Asignación Familiar was implemented. Glewwe and Olinto (2004) conclude that the Program shows a positive effect on school enrollment on the order of $3 \mathrm{pp}$. In the case of Ecuador, Schady and Araujo (2008) estimate a much larger impact of approximately $10 \mathrm{pp}$ on enrollment for the Bono de Desarrollo Humano Program. However, when evaluating the impact of the program on students' cognitive achievements, Ponce and Bedi (2010) find no impacts of the plan on test scores.

In addition, Attanasio, Fitzsimons and Gomez (2005) find that the Familias en Acción Program, instrumented in 2003 in Colombia, has been effective at increasing enrollment, particularly amongst 14- to 17-year-olds, in both urban and rural areas. Likewise, Maluccio and Flores (2005) study of the Red de Protección Social Program in Nicaragua show an increase of $13 \mathrm{pp}$ on school enrollment, one of the largest impacts on the region.

\section{II.1. Argentina's Universal Child Allowance}

The Universal Child Allowance (UCA) was implemented in Argentina in November 2009 by means of Executive Order 1602/2009. This is a non-contributory program that complements the Allocation per Child Program for formal workers ${ }^{1}$. UCA is targeted to those children under 18 years of age who do not receive any other family allocation and whose parents are either unemployed or informal workers with salaries inferior to the adjustable minimum wage. The purpose of this benefit is to contribute to improving the situation of minors living in a social vulnerability context.

UCA consists in a non-remunerative monetary benefit, of ARS 220 per month, per child $^{2}$ - up to a maximum of 5 children- in the following manner: $80 \%$ of the benefit is paid monthly and the remaining $20 \%$ is given to the beneficiary once a year when it is possible to demonstrate that the child has attended a public school ${ }^{3}$ during the school year, that there has been compliance with the vaccination schedule and that the child has received other health check-ups as established by the Ministry of Health ${ }^{4}$. The program is based on the regular mechanisms of the state to check the vaccination and school attendance of children. It was not implemented any additional control such a more frequent monitoring of children's school attendance as exists in other programs ${ }^{5}$.

For details see D'Elia et al. (2010).

2 Originally, the monthly amount of the UCA was ARS 180 per child and, in July 2010 an increase of $22.2 \%$ in the benefit was officially announced.

3 The children can also attend any private school that charges minimum fees for academic learning.

4 The monthly benefit is of ARS 880 per child with a disability, where $80 \%$ is provided directly and the remaining $20 \%$ is effective upon compliance with school attendance, health care check-ups and vaccination schedule requirements. In this case, there is no age limit.

5 For example, the Wisconsin's Learnfare initiative (launched in mid1980s by the state of Wisconsin) is a conditional cash penalty program that sanctions a family's welfare grant when covered teens fails to meet school attendance targets. If an enrolled teen had 10 or more unexcused full-day absences in a semester, they were designated as having poor attendance and were subjected to monthly monitoring. Families on monthly monitoring received monthly notices that reminded them of Learnfare's attendance requirement and offered services designed to assist with school attendance problems (for details, see Dee, 2011). 
According to data provided by the Administración Nacional de Seguridad Social (ANSES), by April 2011 UCA covers 3,549,665 children with a balanced participation of girls and boys. The majority of the beneficiaries (56.6\%) range between 5 and 14 years of age, followed by the group of children under 4 (26\% of total beneficiaries) and by the group aged between 15 and 18 , with a participation of $17.4 \%$.

Concerning education, the data about all the beneficiaries is not yet fully available because it is collected once the beneficiary's parents have submitted a card to ANSES certifying their child's attendance at school during the previous academic year. The information from the 1,655,945 available cards by April 2011 shows that $7.2 \%$ of the children attend kindergarten, $62.7 \%$ attend primary school and $28.3 \%$ attend secondary school (the remaining $1.8 \%$ is in other levels of education). The vast majority attend public schools (more than 90\%), whereas the rest attend private institutions.

What is important to mention is that almost $70 \%$ of the UCA coverage (calculated as the proportion of beneficiaries and children under 18 years of age) is concentrated in the most vulnerable regions of Argentina (the Northeast and Northwest), while the lowest proportion of beneficiaries (18\%) is concentrated in Buenos Aires City ${ }^{6}$. In this respect, some studies show that UCA has contributed to reducing poverty by around 4.2 pp (Gasparini and Cruces, 2010; D’Elia et al., 2010).

\section{DATA}

The data used in this study comes from the Argentinean survey Encuesta Permanente de Hogares $(E P H)$, conducted by the Instituto Nacional de Estadística y Censos (INDEC). The survey covers 31 urban areas, all of which have more than 100,000 inhabitants, representing $71 \%$ of the urban areas of the country and approximately $62 \%$ of the entire Argentinean population. It includes detailed socioeconomic information about individuals and their households, such as education level, employment, earnings, and primary demographic traits.

Unfortunately, the database does not identify who are the beneficiaries of the UCA. To overcome this lack we employ similar criteria to Bertranou and Maurizio (2012); we identify those children in the sample who met the legal requirements for receiving the subsidy and we assumed that they all received it. Given this constraint, we herein defined a child who qualifies for receiving UCA as if he were an actual beneficiary. Based on the requirements for being awarded this benefit, we set three definitions increasingly restrictive on children qualifying for the subsidy. UCA1 includes cases that meet the conditions stated in the Executive Order, namely that both parents are either unemployed or inactive or they are informal workers or domestic servants. This definition does not take into account the wage limit regarding the legal minimum wage required by the Executive Order since checking the earnings of nonregistered employees is actually difficult. Thus, it is possible that a child receives UCA even though his or her parents earn more than such amount in the labour

6 According to INDEC, in the second half of 2010 (the last information available), total poverty was $18.5 \%$ for the Northeast region, $11.8 \%$ in the Northwest and $4.2 \%$ in Buenos Aires City. 
market. The UCA2 definition removes from the sample all children whose parents are self-employed or employers with incomes above the legal minimum wage in both cases. This definition - expanded to taking in account the whole country- produces a number of beneficiaries very similar to Bertranou and Maurizio (2012). The definition of UCA3 also eliminates children whose parents are informal employees but at the $E P H$ survey declares as having incomes over the minimum wage (as required by law). In addition, we also use a survey question about the amounts of the subsidies or social assistance benefits received by the respondents to better identify the potential beneficiaries of UCA. The question does not specify the source of the aid, it could come from the federal government, like UCA, but it could also be received from a sub-national government or a church.

Since the UCA was implemented in November 2009, and at the moment of the estimations there were not $E P H$ survey results corresponding to 2011, the data applied in this study correspond to the surveys collected during the last quarter of 2009 and $2010^{7}$. Using data from the last quarter presents the issue that several children interviewed might not have been certain to have passed grade. Actually, because the schooling calendar in Argentina ends in December, many students are not sure of having moved on to the next grade until the following March, when they receive the results of their exams. Another issue of using data from the last quarter is that all the children in each grade will not be the same age at that point in the year, due to the minimum age specifications in the Argentinean educational system.

This study focuses on children between six and seventeen years old still living with their parents since the cross-sectional structure of the data prevents the study of those children that no longer live in their parents' home. According to the Encuesta de Educación y Empleo de los Jóvenes (Survey of Youth Employment and Education) conducted in June 2005 in Gran Buenos Aires (the largest urban area in the country, GBA) by INDEC and Centro de Estudios Distributivos, Laborales y Sociales (CEDLAS), approximately $95 \%$ of the individuals aged between 15 and 20 live in their parents' home (Navarro, 2011), so, the potential bias due to the cross-sectional structure of the data should not be significant.

The variable used in this study for measuring children's achievement in school is the child's schooling gap, specifically; we use Andersen's definition of schooling gap for children and teenagers (Andersen, 2001). Thus, the schooling gap is defined as the difference between the years of education a child should have completed if he had first entered school at the established age and had advanced one grade each year, on the one hand, and the years of education actually completed, on the other hand. Applying this definition, for example, to a 14-year-old student who has completed seven years of schooling, suggests the existence of a schooling gap of two years (14-7-5=2) if he or she lives in a country where children start school at age five. Hence, the schooling gap reveals the children's school backwardness. This delay may reflect either a late start in school or that the child has repeated a grade. Because the data do not allow differentiating between these situations, and

7 The EPH survey for the last quarter of 2008 was also used to check the robustness of the results. 
it is common in Argentina for all children to start school at the normal starting age regardless of income, this study assumes that schooling gaps reflect a failure to advance to the next grade every year.

In the household survey $(E P H)$, the respondent states the highest level of education (e.g., primary, secondary or university) achieved to date, if completed or not, and the highest grade completed. This information allows calculation of the respondent's years of education. The last question was left unanswered by several respondents, in which cases the variable years of education cannot be defined. However, in those cases where the highest level of education attained was primary or secondary, it is possible to deduce it. For example, an individual who claims to have completed secondary school will have achieved seven years of primary school plus five of secondary school with a total of twelve years of schooling. Unfortunately, this methodology could not be implemented for children whose highest level of education attained was Basic General Education $(E G B)$. This problem arises because $E G B$ consists of nine years of basic education divided into three consecutive levels, which are indistinguishable in the data. Since for these children it is not possible to know with certainty how many years of schooling they have completed, these observations are not included because the size of the schooling gap for them will also be imprecise. Another aspect to consider in calculating years of education is pre-primary schooling. Although one year of kindergarten (for children aged five) was not mandatory until 1993, attending it was quite common. Despite the fact that it cannot be known whether respondents have attended pre-primary school, it is assumed here that all of them have. Taking this assumption into account, in the above example the years of schooling would amount to thirteen. Having defined how many years the child has completed, the schooling gap is calculated as the difference between the age at the time of the interview, the years of schooling he or she has completed and the normal school starting age for Argentina (five years old for those entering kindergarten). Hence, for a 15-year-old student who has completed eight years of education, the schooling gap amounts to one school year. However, as the survey does not provide information regarding the date of birth of individuals, it is not possible to identify those whose birthday is in the second half of the year. Hence, they will appear as being a year behind schedule when they are not. Data from previous surveys that supplied the respondents' birth date show that half of the cases involve students with birthdays in the second half of the year. This limitation in the data covers all observations equally so it does not introduce a particular bias towards children receiving the subsidy.

Table 1 shows that the average schooling gap for all children between six and seventeen years old (whether beneficiaries of the UCA subsidy or not) narrowed by $1.2 \%$ between 2009 and 2010, but the percentage of repeaters, i.e. those who are behind but have not left school is practically the same. In addition, the dropout rate was reduced, on average, by slightly more than $17 \%$ considering both primary and secondary education, the percentage effect being much greater in the first case and the number of students, in the second. Data from the group of older students show a better school performance compared to their younger peers, for whom not only does school backwardness grow, but also the number of students repeating grades. Besides, 


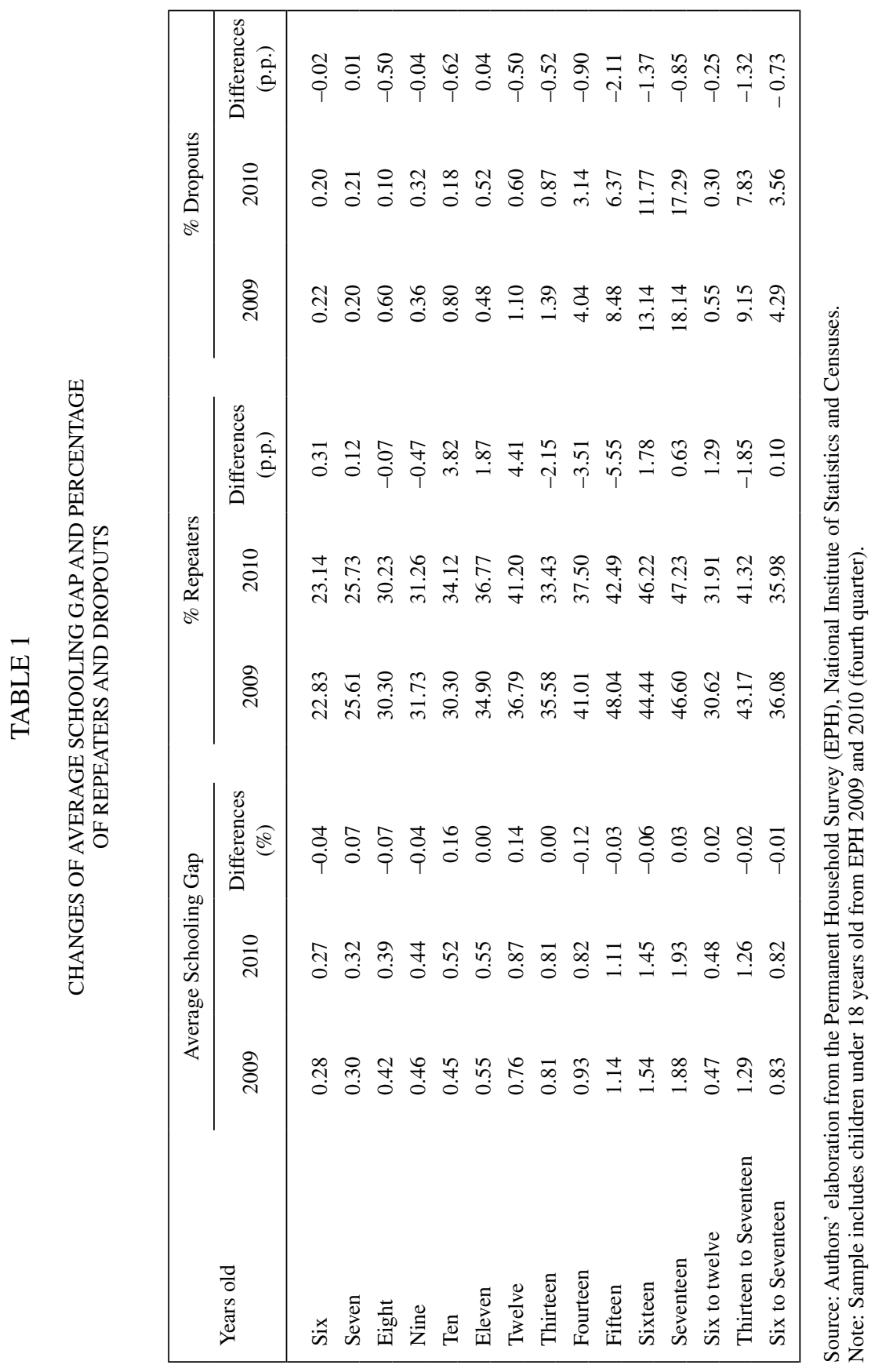


the number of students returning to school is smaller for the younger. Such data seem to show that the effects of UCA are not uniform and depend on the age, skills and motivations of each of the children receiving the subsidy.

However, these results could be affected by the pattern of school backwardness during the years prior to the implementation of UCA. The education gap may have been narrowing or widening every year due to other causes beyond the implementation of the UCA program and the results would be influenced by a trend that had been set earlier. So, it is illustrative to see the patterns of the education gap, the dropout and repetition rates before UCA. Figure 1 shows that, for the younger children (612), the school gap remained virtually unchanged over the seven years prior to the implementation of UCA and, after a period of increase, the percentage of students repeating grades started to fall in 2006; dropouts first rose, then went down and increased again in 2008 and 2009. For the adolescent group, the education gap in terms of the number of students also stayed the same above its lowest level reached in 2005, but the number of students repeating grades decreased more significantly; dropout figures were similar to those for younger children. These results suggest that, although the number of children lagging behind in school went down over the years before the implementation of UCA, for those who did lag behind, the gap widened.

\section{EMPIRICAL STRATEGY}

With the purpose of modeling the effect of receiving the UCA subsidy on a child's educational achievement, this study uses the methodological framework for intergenerational educational persistence as proposed by Behrman, Gaviria and Székely (2001), and redefined by Navarro (2011), adapted to the particular case where the independent variable is children's schooling gap.

$$
S G_{c}=\alpha+\beta U C A_{c}+\chi C_{c}+\delta C_{p}+\gamma C_{h}+w_{c},
$$

where $S G_{c}$ refers to children's years of missing education, $U C A_{c}$ is a dummy variable that equals one when the child and the parent qualify for the subsidy; $C_{c}$ and $C_{p}$ are vectors of children and parental characteristics, respectively, and $C_{h}$ is a vector of household variables; $w_{c}$ is a stochastic term. The reason for choosing the schooling gap as the dependent variable is that it is more accurate than the number of years of education since the latter is not a good measure of the educational attainment of the young because many of them are still in school (Andersen, 2001). The education gap is a rough indicator of future opportunities for children that is often used to study the social mobility of adolescents or young adults when the researcher lacks of longitudinal data (Andersen, 2001; Behrman, Birdsall and Székely, 1998; Conconi et al., 2008; Dahan and Gaviria, 2001; Navarro, 2011).

The parameter of primary interest in the present context is the difference between the average schooling gap of children who receives the UCA aid, an observable figure, and the counterfactual schooling gap there would exist if they did not receive the subsidy. Nevertheless, when comparing the schooling gap observed among children 


\section{FIGURE 1}

\section{AVERAGE SCHOOLING GAP, PERCENTAGE OF REPEATERS AND DROPOUTS 2003-2010}
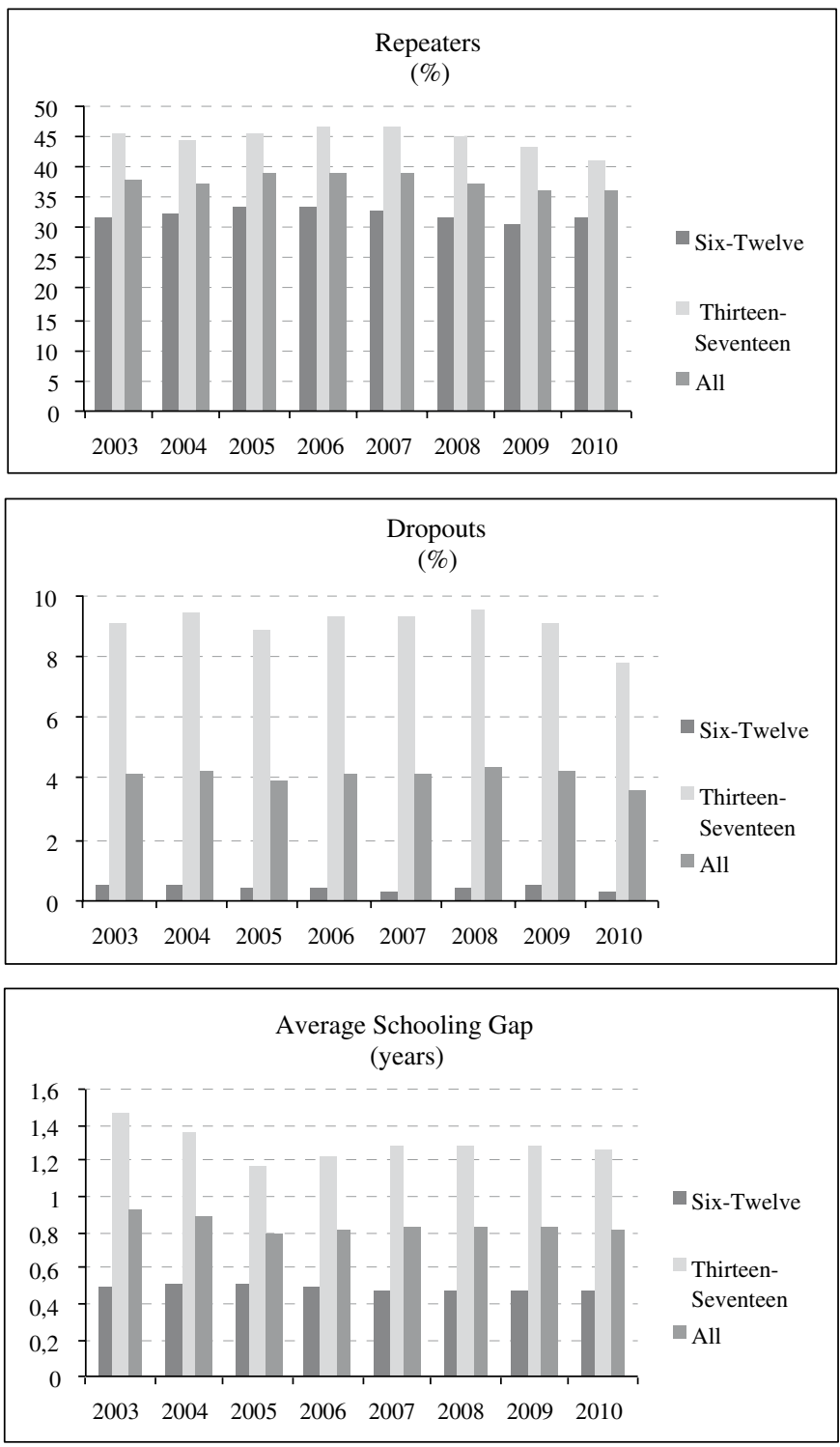

Source: Authors' elaboration from the Permanent Household Survey $(E P H)$, National Institute of Statistics and Censuses.

Note: Sample includes children under 18 years old from EPH 2003 to 2010 (fourth quarter). 
who received the UCA aid and children who did not, we obtain a biased measure of the effect of treatment on the treated, unless the subsidy was granted through a random selection process (Angrist and Pischke, 2008). Indeed, participation in the UCA program is not assigned randomly but it even has a self-selection component. Some of these underlying factors are observable characteristics of the children, such as having parents without a formal job, but others are not. To control for observable factors, the literature usually uses matching techniques (e.g., Galasso and Ravallion, 2003; Gasparini, Haimovich and Olivieri, 2007). According to Rosenbaum and Rubin (1983), matching methods estimate the control group outcome by taking weighted averages for individuals who did not participate in the program but are observationally similar to those who did. This method calculates propensity scores, defined as the probability of participating conditional on observed (predetermined) covariates $x_{i}$. Following Angrist and Pischke (2008), we selected two observational control groups from the $E P H$ surveys using the propensity score as a precursor to regression estimation. The first comparison group is composed by all the children under eighteen years old, and the second one is a narrower comparison group due to the UCA program rules, which favors children whose parents do not have a formal job. The second group allows making a kind of before-after impact evaluation. Then, the study follows the approach proposed by Crump et al. (2006) by first estimating the propensity score of a pool of $E P H$ children -treated and not treated-and then picking only those observations with a predicted probability of treatment between $20 \%$ and $80 \%{ }^{8}$. This ensures that OLS regressions are estimated with a sample including only covariate cells with at least a few treated and control observations ${ }^{9}$. In this sense, we estimate the following probit model for the probability of UCA:

$$
P\left(U C A_{c}=1 \mid x\right)=G\left(\chi C_{c}+\delta C_{p}+\gamma C_{h}\right)
$$

where $C_{c}, C_{p}$ and $C_{h}$ are the same vectors of children, parental and household characteristics as those in Eq. (1).

The impact of UCA on the students' backwardness cannot be determined in advance and, therefore, the sign of the $\beta$ coefficient cannot be defined either. On the one hand, students returning to school because of UCA are likely to be more backward than those who attend regularly, but we cannot be certain whether they have enough motivation to succeed in their studies. On the other hand, high-achieving students currently attending school can benefit from the money aid improving their academic performance and decreasing their school backwardness, but a low-achieving student who remains in school in order to obtain the grant is unlikely to improve his or her school performance. It might also be expected that the effect of the subsidy is different

8 Additional estimates were made with predicted probabilities between 10 and $90 \%$. These estimates yield results very similar to those performed with the probability interval 0.2 to 0.8 , but the control group in the latter case is more similar to the group defined as treated from the EPH.

9 We also performed a negative binomial regression to check the efficiency of the results of the OLS model and the results are consistent with those of the least squares regression. 
between children and adolescents. One reason for this is the involvement of teachers and parents in primary school students, much less in high school where the multiplicity of teachers makes it less possible.

Using EPH survey data for the last quarter of 2010, each alternative definition of the UCA requirements produces a different sample of treated children. As mentioned above, for the control group we define two alternative groups: the first " $P$-score Screened Sample (full sample)" used all the observations of children under eighteen from the EPH survey for the last quarter of 2009, the second -more restrictive- one " $P$-score Screened Sample (before-after)" uses the group of observations that could have qualified for receiving UCA in the last quarter of 2009. The definition of the control variables is the same as in Navarro (2011).

Descriptive statistics for both unscreened and screened samples of $E P H$ (screened on the score but using the full set of covariates) appear in Table A.1 of the Annex. Differences in child and household characteristics between the treatment and control group are noticeable, as one would expect since the assignment was not random. It is also shown the covariate means of both $P$-score screened samples are much closer to the $E P H$ treated sample means (column 1) than to the covariate means of the unscreened sample in column 5, especially in regard to the characteristics of the household.

To check if the treated group identified in the EPH (last quarter 2010) is similar to the group that actually receives the subsidy (identified using ANSES data for April 2011), Table 2 compares proportions and means of individual characteristics of the UCA beneficiaries. In general, there is not much difference in children characteristics between ANSES and EPH groups. The difference in the private school variable arises because in the $E P H$ it is not possible to identify those private schools that charge minimum fees for academic learning. Apart from that, the GBA and Pampeana region are not directly comparable since the definitions of these regions differ in both databases.

Table 2 also presents the statistics for characteristics of parents whose children are actually beneficiaries of $\mathrm{UCA}_{1}{ }^{10}$; however, it is not possible to make a similar comparison with those for child characteristics. This is because the child's mother, father or guardian could receive the subsidy, so the comparison group in the $E P H$ is not clearly defined. Apart from that, although the member of the child's family who receives UCA could be accurately identified, as they report their labour status (unemployed, informal worker, etc.), there might be a bias between what they report and their actual status. When adjusting the definitions of UCA with questions relating to income assistance (see below in the robustness analysis), the statistics do not differ much, but the number of observations changes; the $\mathrm{UCA}_{1}$ definition comes closest to ANSES data.

As for the effect of parents' educational level, the $\beta$ coefficient is expected to be negative as long as higher parental education prevents children from falling behind in school. It is also expected that $\beta$ is far from one because, according to the empirical literature, there is a low generational dependence for children who still live with their parents and are attending school in Argentina (Conconi et al., 2007; Fernández, 2006; Navarro, 2011).

10 Similar results are obtained for the other definitions of UCA, namely $\mathrm{UCA}_{2}$ and $\mathrm{UCA}_{3}$. 
TABLE 2

COMPARISON OF COVARIATES FROM ANSES AND EPH DATA

\begin{tabular}{|c|c|c|c|c|}
\hline \multirow{3}{*}{ Variable } & \multicolumn{4}{|c|}{ Treated } \\
\hline & \multicolumn{2}{|c|}{ ANSES } & \multicolumn{2}{|c|}{$E P H$} \\
\hline & $\begin{array}{l}\text { Mean/ } \\
\text { Prop. }\end{array}$ & Std. Dev. & $\begin{array}{l}\text { Mean/ } \\
\text { Prop. }\end{array}$ & Std. Dev. \\
\hline \multicolumn{5}{|l|}{ Children characteristics } \\
\hline Children age & 8.80 & 5.10 & 8.79 & 5.46 \\
\hline Boys & 0.51 & 0.50 & 0.51 & 0.50 \\
\hline Private school & 0.09 & 0.29 & 0.22 & 0.41 \\
\hline GBA region & 0.04 & 0.19 & 0.47 & 0.50 \\
\hline NOA region & 0.17 & 0.38 & 0.14 & 0.33 \\
\hline NEA region & 0.15 & 0.35 & 0.08 & 0.27 \\
\hline Cuyo region & 0.07 & 0.26 & 0.08 & 0.27 \\
\hline Pampeana region & 0.53 & 0.50 & 0.21 & 0.41 \\
\hline Patagónica region & 0.04 & 0.20 & 0.03 & 0.16 \\
\hline \multicolumn{5}{|l|}{ Parents's characteristics } \\
\hline Age (man parent) & 41.98 & 9.39 & 43.8 & 12.53 \\
\hline Age (woman parent) & 32.98 & 8.04 & 45.32 & 14.33 \\
\hline Unemployed & 0.95 & 0.22 & 0.06 & 0.23 \\
\hline Informal worker & 0.02 & 0.16 & 0.73 & 0.44 \\
\hline Domestic servants & 0.03 & 0.16 & 0.07 & 0.26 \\
\hline Inactive population & nd & nd & & \\
\hline Number of beneficiaries & \multicolumn{2}{|c|}{$3,549,665$} & & \\
\hline $\mathrm{UCA}_{1}$ & & & \\
\hline $\mathrm{UCA}_{2}$ & & & \multicolumn{2}{|c|}{$2,997,201$} \\
\hline $\mathrm{UCA}_{3}$ & & & \multicolumn{2}{|c|}{$2,584,734$} \\
\hline
\end{tabular}

Source: Authors' elaboration from the Permanent Household Survey $(E P H)$, National Institute of Statistics and Censuses and from the Administración Nacional de la Seguridad Social (ANSES).

Note: The sample includes observations from EPH 2010 (fourth quarter) that meet the requirements of the UCA1 definition. In $E P H$ sample, parents' data correspond to household head data. There are some differences in the definition of regions between ANSES and EPH. In the ANSES data, $G B A$ region refers to $C A B A$ and the province of Buenos Aires is included in Pampeana region. All variables have been expanded to total population.

\section{RESULTS}

As mentioned above, the favorable or unfavorable effects of UCA on children's school performance are not, a priori, conclusive since there are arguments supporting both positions. However, Table 3 shows, for the full sample, simple nonparametric estimates of the schooling gap due to the status of children as beneficiaries of UCA, and the results (without controlling for any individual or household characteristics) do suggest that children who benefit from UCA have worse school performance than those who do not receive it. This simple exercise also shows that the UCA affects favorably the adolescents but not the children. 


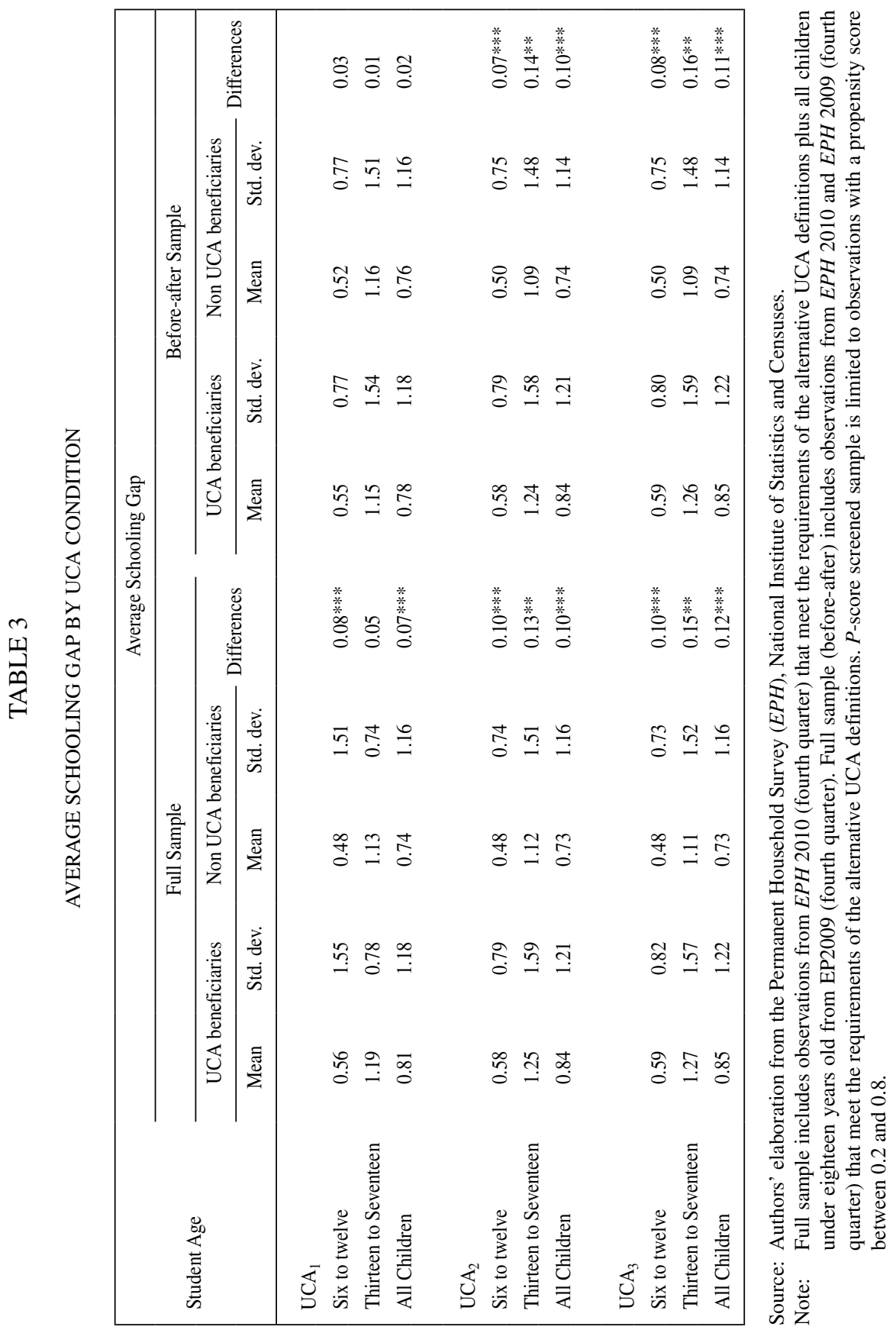


Table 4 displays the results of estimating a restricted version of the model presented in Eq. (1) using schooling gap as the dependent variable and the children's status regarding the UCA, a dummy variable that takes a value of one for children receiving the aid, as the independent variable ${ }^{11}$. The results use the full sample as the comparison group, which includes all children under eighteen years old in the last quarter 2009 $E P H$ survey. This exercise reveals the unconditional effect of receiving UCA, which accounts for the positive or negative sign of it. Since the gap necessarily depends on children's age, although the estimations are made for two different age groups (six to twelve and thirteen to seventeen) as well as for the whole sample, children's age is included even in this unconditional exercise. The results broadly show the enlargement of the educational gap for those receiving the UCA subsidy. For the children under thirteen years old, the UCA coefficients are positive and statistically significant at a $5 \%$ and $1 \%$, but for the older students, despite being positive, the coefficients are not statistically significant. This result is robust for the three definitions of the UCA beneficiaries and the coefficients are very similar to each other.

The above results suggest that younger children who meet the legal requirements to receive the UCA subsidy have worse academic performance and, additionally, that the UCA benefit seems not to be effective in improving the quality of their education. From Table 1 it is evident that in 2010 the percentage of students returning to primary school was minimal in this age group mainly because the percentage of dropouts in 2009 was also minimal. So, for this age group, the unconditional unfavorable impact of the UCA subsidy on a child's schooling gap affects those students who attended school regularly before the implementation of the UCA program. In Table 4, it is apparent that for those pupils attending primary school, even though the subsidy can help them to stay on at school, it does not help them to be promoted to the next grade. These results support the idea that low-achieving students do not succeed in improving their academic performance with the subsidy. However, for those attending secondary school, even if the unconditional estimates have the same sign as for young children, they are not statistically different from zero.

Table 5 shows the unconditional results by using the before-after Sample for the regressions. In this sample the control group is only made up of children who met the program requirements in the EPH survey for the last quarter of 2009. Broadly, the results are similar to those obtained above, but there is a significant reduction in the number of UCA coefficients, with appropriate levels of statistical significance. Using this restricted sample, there are only two positive and statistically significant coefficients, of both the $\mathrm{UCA}_{2}$ subsample for the younger children and the whole group of children aged between 6 and 17 .

By adding control variables for individual characteristics and family background, we obtain broadly similar results but this exercise also reveals some interesting features of the school backwardness phenomenon. The results for the full sample are presented

11 Since the UCA variable could be linked to the unobservables in Eq. (1), we tested endogeneity using as our instrument a dummy variable that indicates if the household member (son, grandchildren, daughter and son in law, and other relatives) is a child under 18, but we were not able to reject the null hypothesis of exogeneity. 


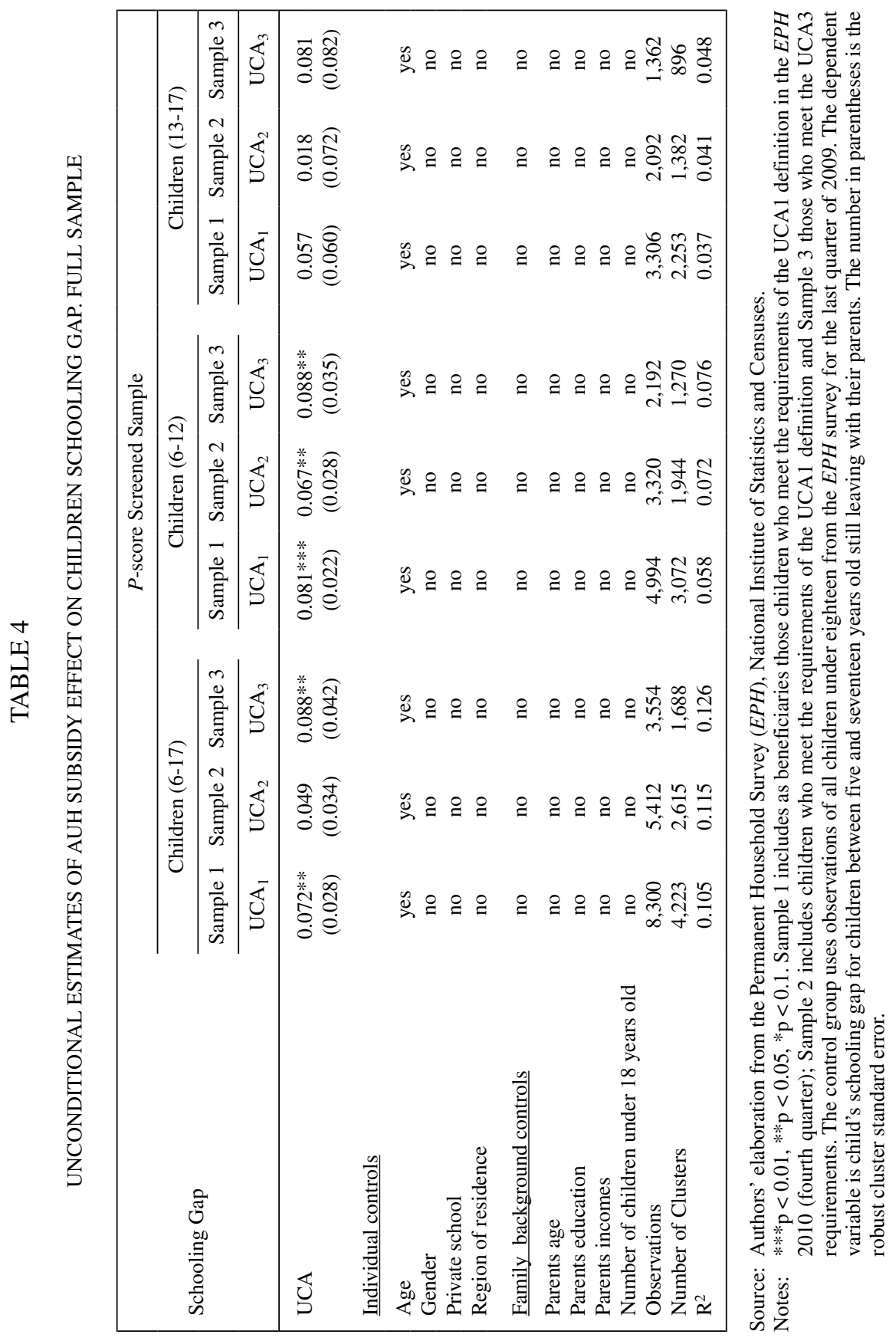




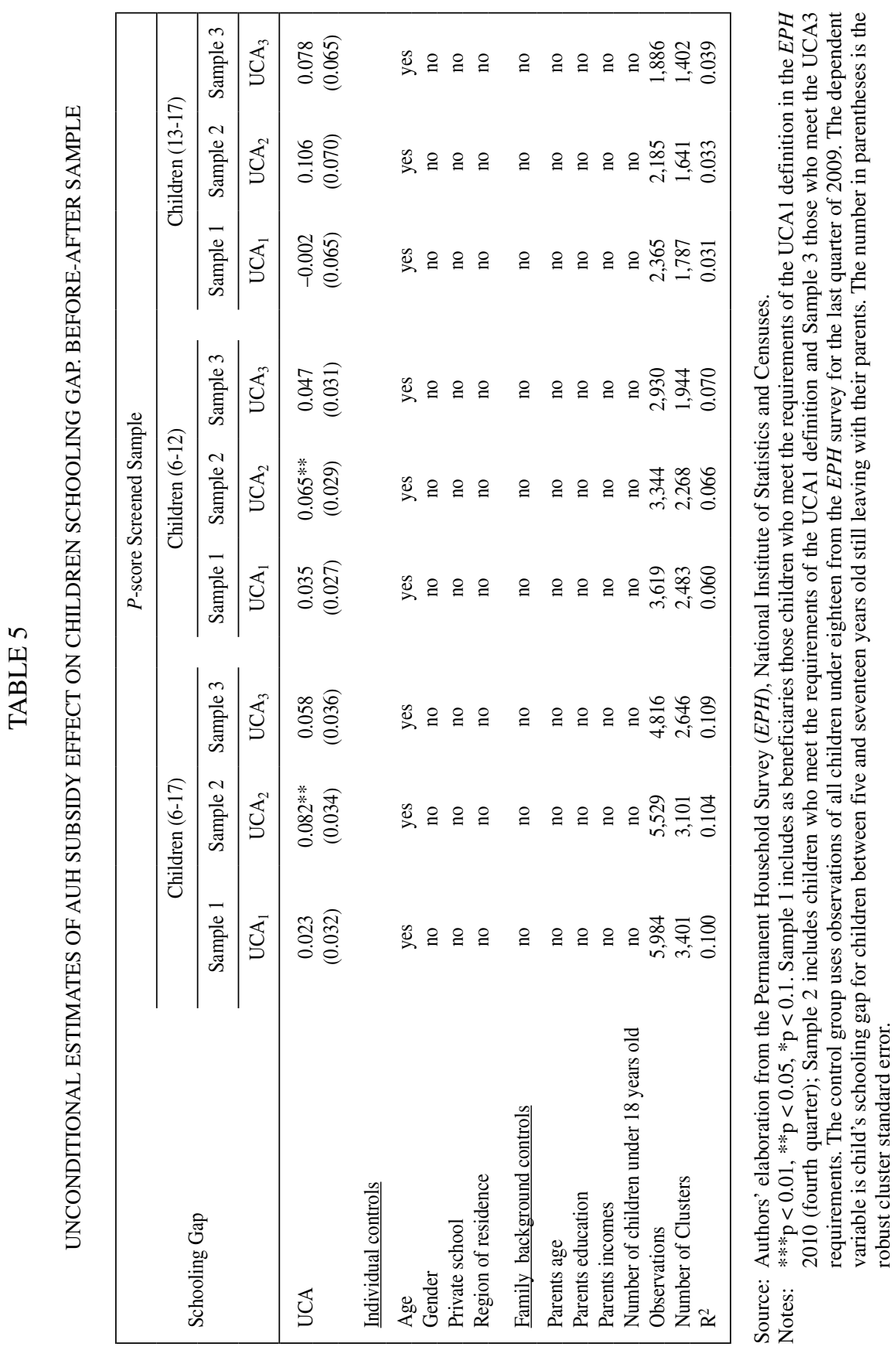




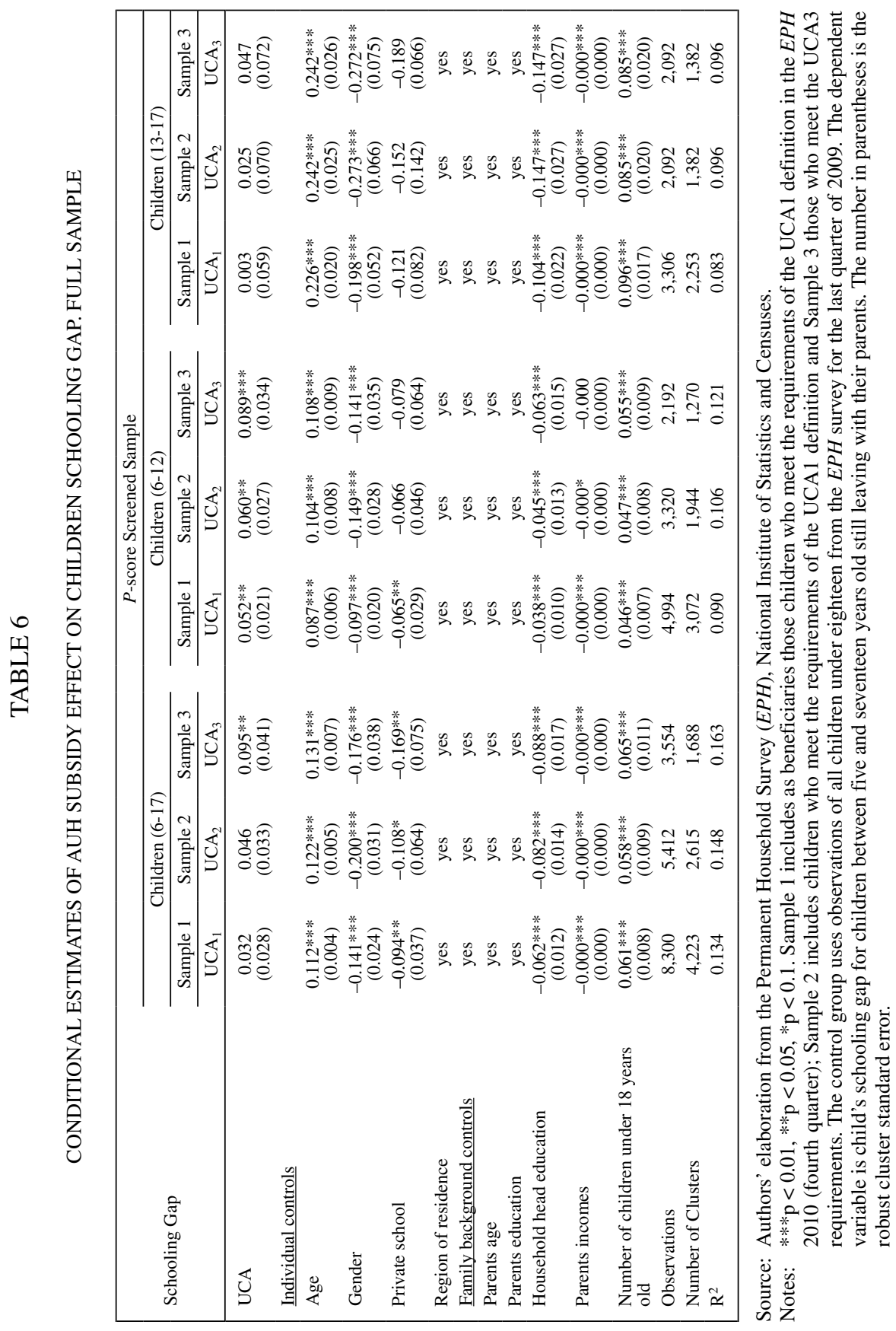




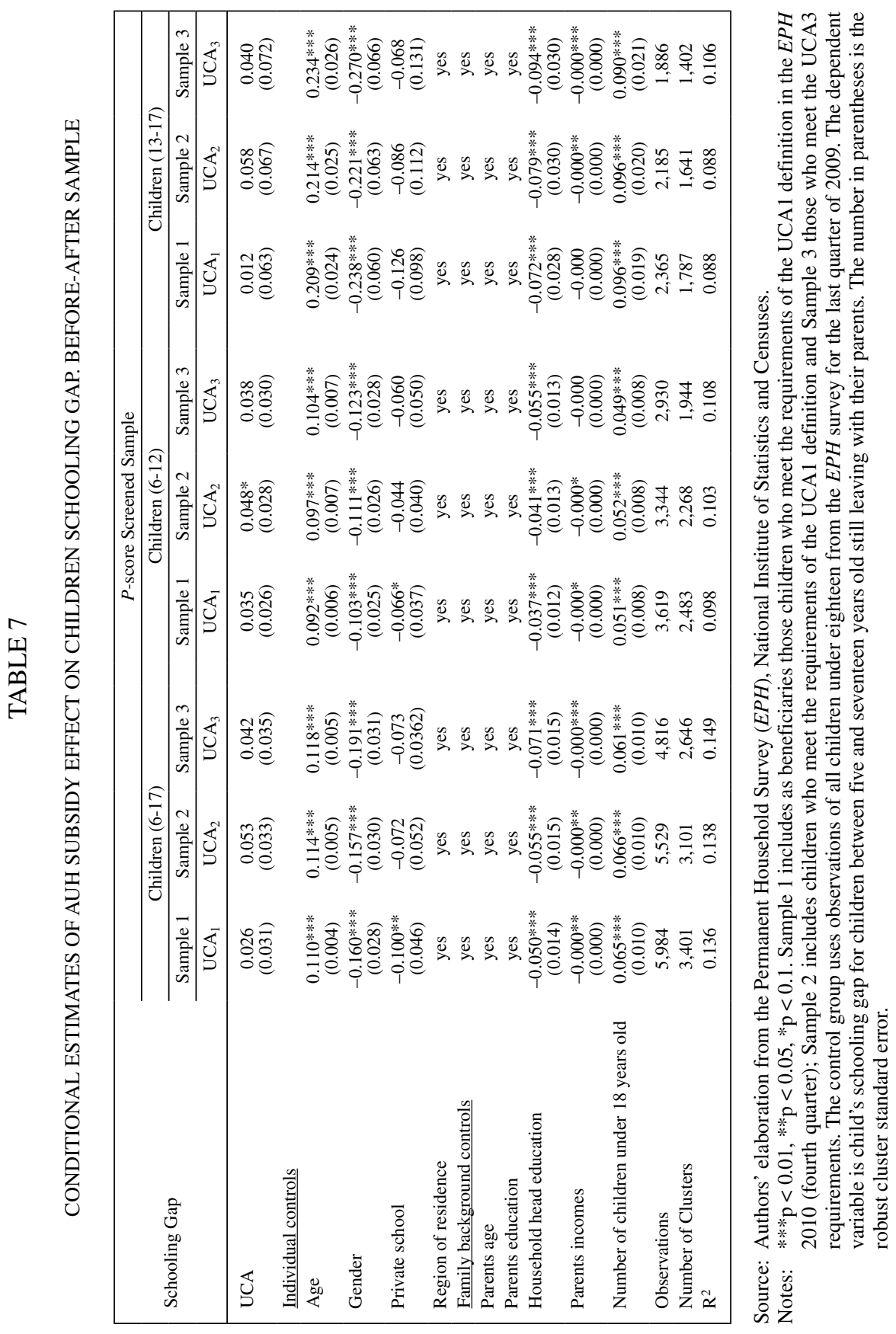


in Table 6 and show a clearer picture about the effects that receiving the subsidy may have on children, whether they are young children or adolescents. For both groups, the allowance enlarges the educational gap, but only for younger children is this effect statistically significant at 5\% and $1 \%$.

As expected, the level of parental education reduces children's schooling gap, but this effect is larger for children older than thirteen than for the younger ones. This result applies to an education system in which primary, not secondary, education is compulsory for children, such as the one that prevailed in Argentina until 2006. In this case, since secondary school was not mandatory, the education level of parents has a strong effect on adolescents when deciding whether to attend secondary school or not (Navarro, 2011). All these coefficients are statistically significant at $1 \%$. Nevertheless, although for the period under analysis secondary school is mandatory, the large dropout rate shown in Table 1 for this group of adolescents seems to indicate that such condition is not met.

The gender dummy has a negative and significant effect on the mean schooling gap, suggesting that the expected performance of boys is below that of girls. The school type (private or public) coefficient is negative, indicating that those children attending private schools tend to be less backward than the children attending public schools, but the coefficients are mostly statistically insignificant. The number of children under eighteen years living in the same house has a negative impact on their school performance, the coefficients being statistically significant at $1 \%$. The results also indicate that the schooling gap tends to diminish as the family income rises, though it is apparent that the effect is insignificant; the coefficient is statistically significant at the $1 \%$ level.

The conditional estimates using the before-after Sample are shown in Table 7. The coefficients associated with receiving the UCA subsidy have roughly the same general magnitude obtained with the full sample but now only one coefficient remains statistically significant. As when considering the full sample as the control group, the results show that UCA has a negative statistical impact (positive coefficient sign) on the group of children between 6 and 12 years old. The behaviour of the control variables was quite similar to that observed in the full sample.

\section{V.I. CHECKING ROBUSTNESS}

To check the robustness of the results obtained previously, the samples were selected again taking into account the conditions for the enrolment in the UCA and whether the student's parents receives any other kind of public subsidies or welfare. In this way we obtain a more precise identification of the beneficiaries of the UCA. With this correction, the beneficiaries are children under 18 years whose parents do not have state pension contributions nor receives other social assistance incomes. More precisely, 3,093,726 children have been identified to be covered by the $\mathrm{UCA}_{1}$ definition, while 2,419,723 and 2,381,616 children have been identified to be included in the $\mathrm{UCA}_{2}$ and $\mathrm{UCA}_{3}$ definitions, respectively. Table A. 2 and Table A. 3 of the Annex show the estimation results obtained with this redefined samples. 
As can be seen, despite the large drop in the sample size, the magnitudes and signs of the coefficients are broadly similar to those of Table 6 and Table 7, however, the effect of the UCA subsidy is higher when using the corrected sample. On average, the educational gap for those children who receive the UCA benefit is two times the impact estimated with the unrestricted samples (Table 6 and Table 7). So, these results suggest that for those children who attend primary school, the allowance enlarges the educational gap between 0.06 and 0.17 years of schooling (depending on the UCA definition taken into account) compared with those children who do not receive the benefit. On the contrary, the subsidy seems to have no impact on the educational gap of children who attend secondary school ${ }^{12}$.

\section{CONCLUDING REMARKS}

In Latin America cash transfer programs have been very popular in recent years. Empirical evidence proves that they have been an effective tool against current poverty; however, evidence regarding longer-term impacts is scarce. In the case of Argentina, some studies show the positive effects of the Universal Child Allowance (UCA) program in reducing poverty, while data from the Ministry of Health and Education confirm the improvement in child vaccination and school attendance rates. In this sense, it seems that the targets of the UCA program are being met.

In this paper, we go one step further and, using an econometric technique that assures a common support for all the cells included in the estimations, we analyze the potential effects of UCA on its beneficiaries' school achievement. Using three different definitions to determine a child's eligibility for UCA and several different sample specifications to improve the estimations, the results are displayed in Tables 4-7 and in the Annex. In broad terms, the estimations proved to be robust to the alternative definition of UCA and different samples, and the sign of the coefficients does not change across them.

When considering all children under 18 years old, it is not clear enough whether UCA affects the schooling gap because the statistical significance depends on the control group considered, but this ambiguity disappears when using a more precise definition of UCA that takes in account the EPH information about the payment of social assistance. In this case, the results show that the program has an unfavorable impact on the schooling gap of the allowance beneficiaries for the majority of the alternative definitions of $\mathrm{UCA}$ (i.e. $\mathrm{UCA}_{2}$ and $\mathrm{UCA}_{3}$ ).

12 To complete the robustness checks we have also performed a falsification test using data from the $E P H$ of the last quarter of 2005 and 2006. The estimated AUH coefficients for the different specifications of the schooling gap model were not statistically significant in any case meaning that as there is no significant difference between eligible and non-eligible children before the implementation of the program. In addition, we have tested the impact of the allowance over the type of medical coverage for eligible children -an outcome we think is not affected by the subsidy- and as expected, we could not found any significant effect. 
Furthermore, we found that when children are divided by age groups, the UCA subsidy has a significant effect in enlarging the educational gap for those children aged between 6 and 13 (who are generally in primary school). However, the results do not show any significant impact of the allowance on the adolescents' academic performance. Hence, it is apparent that UCA encourages younger children to remain in school although, at least for the short period analyzed in this study, this could mean they have to repeat their current grade. Nevertheless, in the long run, since children remain in school, repeaters may eventually graduate this being a positive effect of UCA not measured in this study. As for the oldest students, the non-significant impact of UCA on the schooling gap could suggest that the subsidy does not contribute to offsetting the high dropout rates, which would have a negative impact on labour prospects.

Therefore, even if UCA has improved school attendance in general, these results suggest that complementary public policies, more oriented to the improvement of the quantity and quality of education, should be implemented. For example, besides the requirement of school attendance, some requirement or incentive regarding grade promotion could also be included. Yet, in order to make such implementation, it is necessary to offer, at the same time, academic support to children with learning difficulties. In this regard, both school attendance and the improvement in academic performance will enhance the effects of UCA, specially because such benefit impacts not only on the future opportunities of children who receive it, but also on the educational achievement of their classmates, irrespective of whether they receive the allowance or not. 


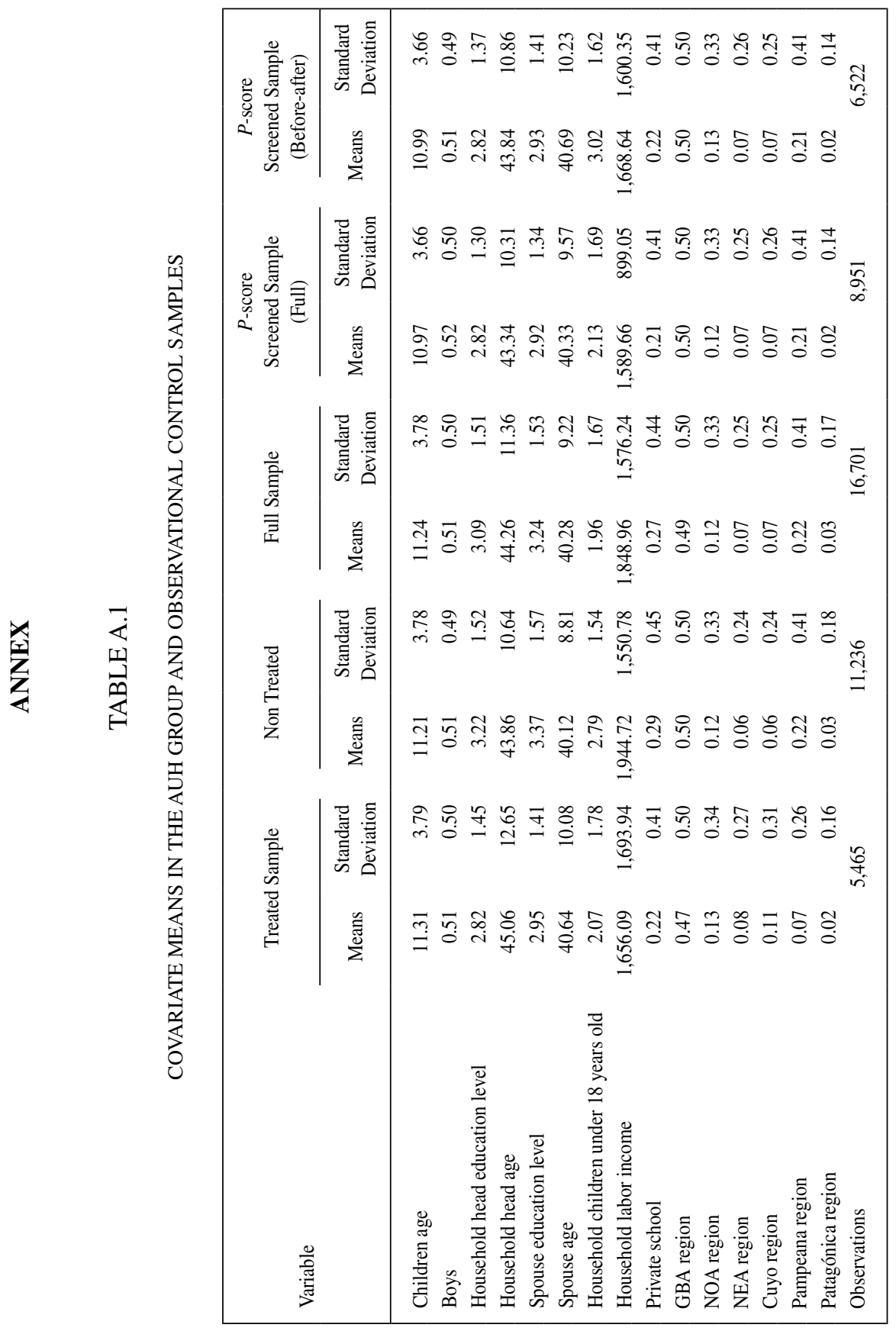




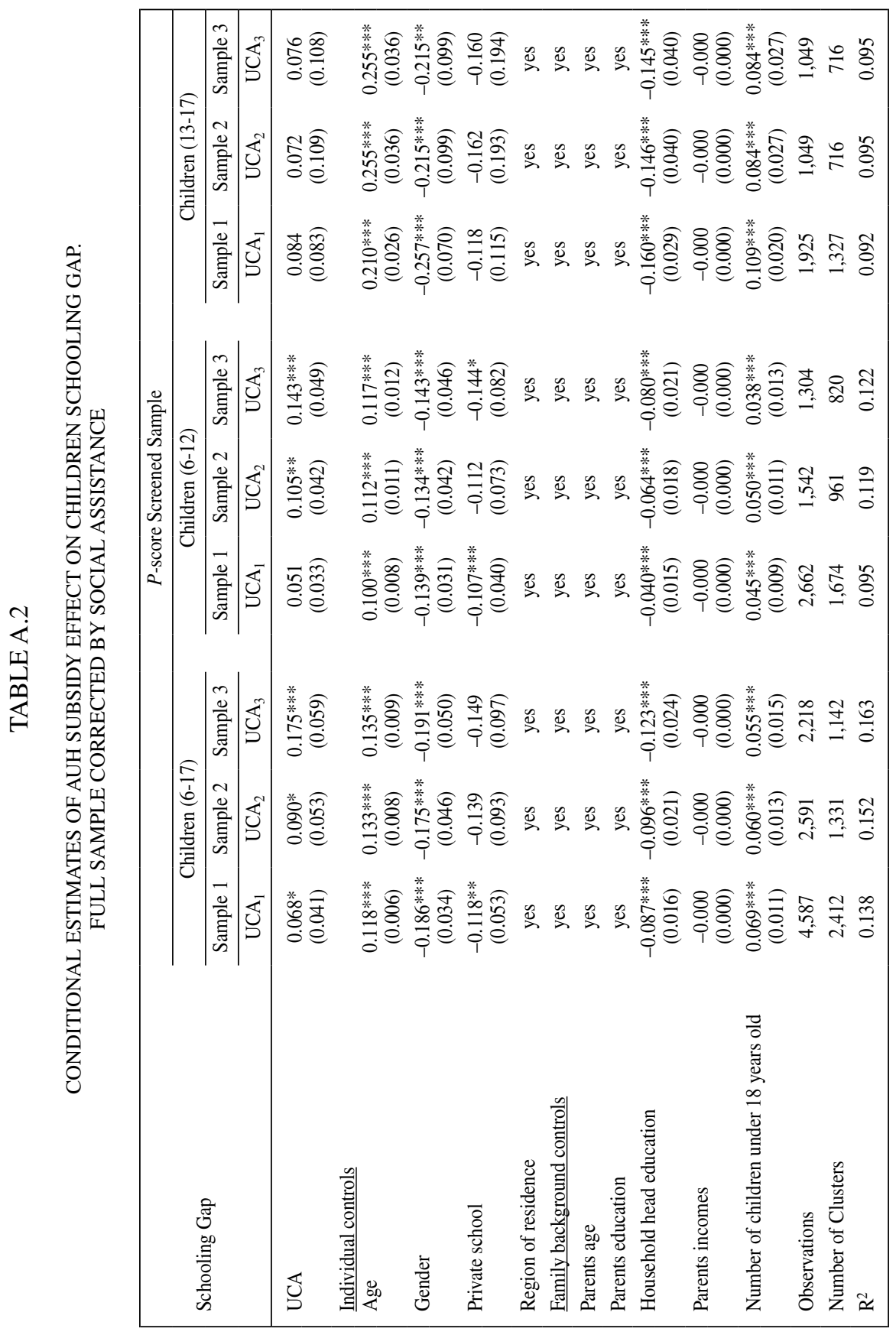




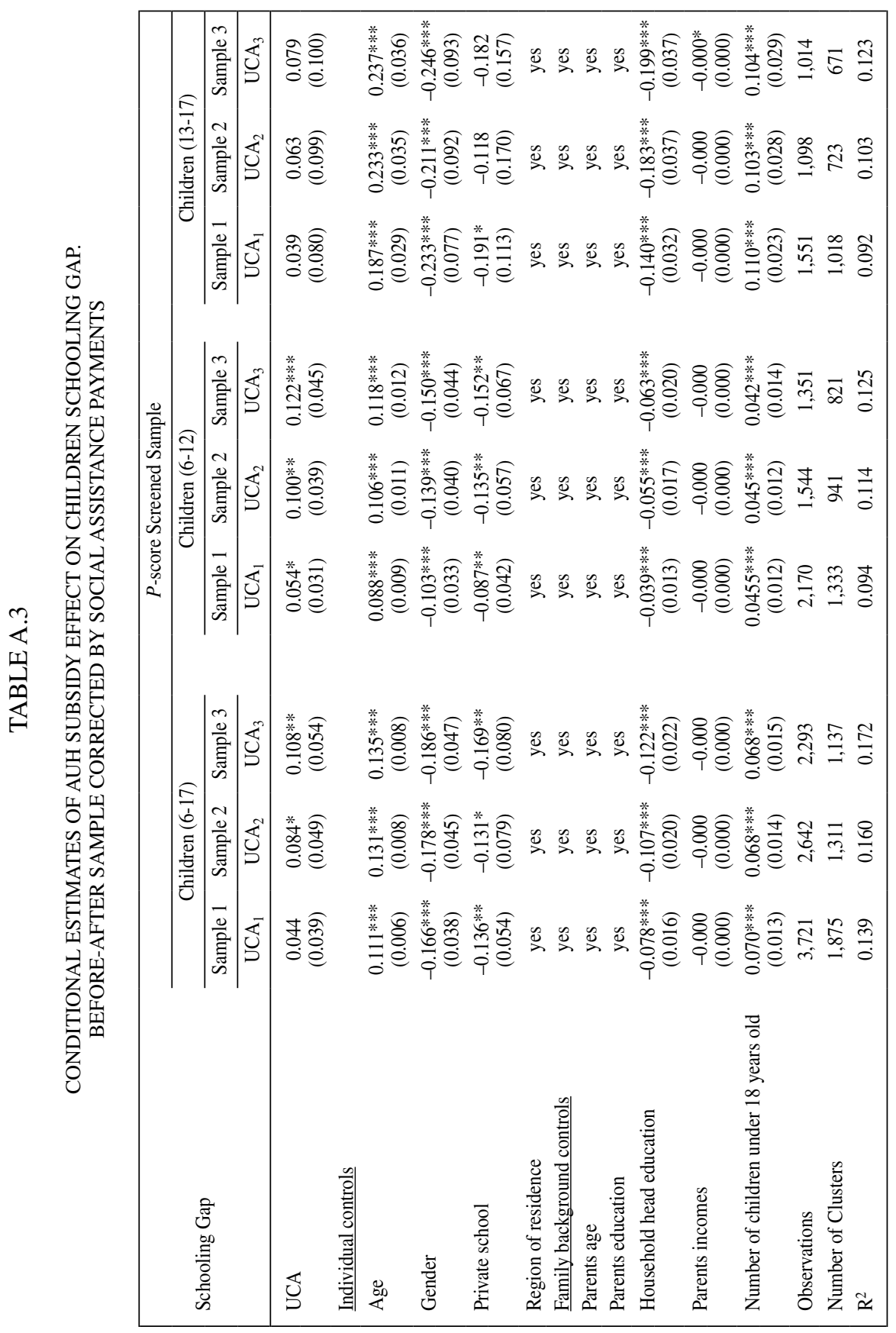




\section{REFERENCES}

ANDERSEN, L. (2001). Social mobility in Latin America: Links with Adolescent Schooling, IADB Research Network. Working Paper R-433, Washington, D.C.

ANGRIST, J.D. and J. PISCHKE (2008). Mostly Harmless Econometrics: An Empiricists Companion, Princeton University Press.

ATTANASIO, O.; E. FITZSIMONS and A. GOMEZ (2005). "The impact of a conditional education subsidy on school enrolment in Colombia”. IFS Briefing. Available at http://www.ifs.org.uk/edepo/ rs_fam01.pdf [Accessed March 5, 2013].

BAEZ, J.E. and A. CAMACHO (2011). Assessing the Long-term Effects of Conditional Cash Transfers on Human Capital: Evidence from Colombia. IZA, Discussion Paper 5751.

BEHRMAN, J.; N. BIRDSALL and M. SZEKELY (1998). Intergenerational Schooling Mobility and Macro Conditions and Schooling Policies in Latin America. IADB Research Department. Working Paper (386). Washington, D.C.

BEHRMAN, J.; A. GAVIRIA and M. SZEKELY (2001). Intergenerational mobility in Latin America. Working Paper $\mathrm{N}^{\circ}$ 452. Inter-American Development Bank. Research Department, Washington, D.C.

BEHRMAN, J.R.; S.W. PARKER and P.E. TODD (2005). "Long-Term Impacts of the Oportunidades Conditional Cash Transfer Program on Rural Youth in Mexico", Discussion Paper 122. Göttingen, Germany: Ibero-America Institute for Economic Research.

BEHRMAN, J.R. and S.W. PARKER (2008). "Following Young Adults Who Benefited from Oportunidades for Nearly a Decade: Impact of the Program on Rural Education and Achievement, 10 Years of Intervention". In: Secretaría de Desarrollo Social (Eds.), External Evaluation of Oportunidades 2008 in Rural Areas (1997-2007) 1, pp. 201-238.

BERTRANOU, F. and R. MAURIZIO (2012). "Semi-conditional cash transfers in the form of family allowances for children and adolescents in the informal economy in Argentina", International Social Security Review 65, pp. 53-72.

BOBONIS, G. and F.F. FRED (2009). "Endogenous Social Interaction Effects in School Participation in Rural Mexico", Review of Economics and Statistics 91 (4), pp. 695-716.

CENTRO DE ESTUDIOS EN POLITICAS PUBLICAS (CEPP) Y UNIVERSIDAD DE BUENOS AIRES Y BANCO SANTANDER RIO (2011). "Informe de Resultados: Asignación Universal por Hijo (AUH), Observatorio de la Educación Básica Argentina”. Available at http://www.fundacioncepp. org.ar/wp-content/uploads/2012/03/Presentacion-AUH.pdf [Accessed March 5, 2013].

CONCONI, A.; G. CRUCES; S. OLIVIERI and R. SANCHEZ (2008). "E Pur si Muove? Movilidad, Pobreza y Desigualdad en América Latina”, Económica 54 (1-2), pp. 121-159.

CRUMP, R.K.; V.J. HOTZ; G.W. IMBENS and O.A. MITNIK (2006). Moving the Goalposts: Addressing Limited Overlap in the Estimation of Average Treatment Effects by Changing the Estimand. New York, National Bureau of Economic Research, Technical Working Paper 330.

DAHAN, M. and A. GAVIRIA (2001). "Sibling Correlations and Social Mobility in Latin America", Economic Development and Cultural Change 49 (3), pp. 537-555.

DEE, T.S. (2011). "Conditional cash penalties in education: Evidence from the Learnfare experiment", Economics of Education Review 30 (5), pp. 924-937.

D'ELIA, V.; A. CALABRIA; A. CALERO; J. GAIADA and S. ROTTENSCHWEILER (2010). "Asignación Universal por Hijo para Protección Social: Una política de Protección para los más vulnerables", Revista del Centro Interamericano de Estudios de la Seguridad Social (CIESS) 260, Conferencia Interamericana de Seguridad Social (CISS), México.

FERNANDEZ, A.G. (2006). Alternative measures of intergenerational social mobility in Argentina. Anales de la Asociación Argentina de Economía Política.

FISZBEIN, A. and N. SCHADY (2009). "Conditional Cash Transfers: Reducing Present \& Future Poverty". World Bank, Washington D.C. Available at http://web.worldbank. org/ WBSITE/EXTERNAL/EXTDEC/EXTRESEARCH/EXTPRRS/EXTCCT/0,,content MDK:22040461 pagePK:64168427 piPK:64168435 theSitePK:5757745,00.html [Accessed March $5,2013]$.

GALASSO, E. and M. RAVALLION (2004). "Social Protection in a Crisis: Argentina's Plan Jefes y Jefas", The World Bank Economic Review 18 (3), pp. 367-399. 
GALASSO, E. (2006). With Their Effort and One Opportunity: Alleviating Extreme Poverty in Chile. Unpublished manuscript, World Bank, Washington, D.C.

GASPARINI, L.; F. HAIMOVICH and S. OLIVIERI (2007). Labor Informality Effects of a PovertyAlleviation Program. CEDLAS. Documento de Trabajo $\mathrm{N}^{\circ} 53$.

GASPARINI, L. and G. CRUCES (2010). Las asignaciones universales por hijo. Impacto, discusión y alternativas, Documento de Trabajo CEDLAS 102, Universidad Nacional de la Plata, Argentina.

GLEWWE, P. and L. KASSOUF (2012). "The impact of the Bolsa Escola/familia Conditional Cash Transfer Program on Enrolment, Grade Promotion and Drop Out Rates in Brazil", Journal of Development Economics 97 (2), pp. 505-517.

GLEWWE, P. and P. OLINTO (2004). Evaluating the Impact of Conditional Cash Transfers on Schooling: An Experimental Analysis of Honduras. Unpublished manuscript, University of Minnesota.

GONZALEZ ROZADA, M. (2010). "Las AUH: ¿pan para hoy, hambre para mañana?”. Available at http:// focoeconomico.org/2011/05/25/las-auh-\%C2\%BFpan-para-hoy-hambre-para-manana/ [Accessed March 5, 2013].

IEG (Independent Evaluation Group) (2011). Social Safety Nets: An Evaluation of World Bank Support, 2000-2010. Washington, D.C.: Independent Evaluation Group, the World Bank Group.

MALUCCIO, J.A. and R. FLORES (2005). Impact Evaluation of a Conditional Cash Transfer Program: The Nicaraguan Red de Protección Social, Research Report 141. International Food Policy Research Institute, Washington, D.C.

NAVARRO, A.I. (2011). "Effect of Argentinean Program for Unemployed Heads of Households on Children's Schooling Gap", International Business: Research, Teaching and Practice 5 (2), pp. 60-86.

PEROVA, E. and R. VAKIS (2009). Welfare Impacts of the "Juntos" Program in Peru: Evidence from a non-experimental evaluation. World Bank, Washington, D.C.

PONCE, J. and A.S. BEDI (2010). "The impact of a cash transfer program on cognitive achievement: The Bono de Desarrollo Humano of Ecuador", Economics of Education Review 29 (1), pp. 116-125.

SCHADY, N. and M.C. ARAUJO (2008). "Cash Transfers, Conditions, and School Enrollment in Ecuador", Economía 8 (2), pp. 3-70.

SKOUFIAS, E. and B. MCCLAFFERTY (2001). Is PROGRESA working? Summary of the results of an evaluation by IFPRI. Food Consumption and Nutrition Division (FCND), Discussion Paper $\mathrm{N}^{\circ} 118$, Washington, D.C.

SOARES, F.V.; R. PEREZ RIBAS and R. GUERREIRO OSORIO (2010). "Evaluating the Impact of Brazil's Bolsa Familia: Cash Transfer Programs in Comparative Perspective", Latin American Research Review 45 (2), pp. 172-190. 